\title{
EXPERTS USE COMPENSATORY STRATEGIES MORE OFTEN THAN NOVICES IN HIRING DECISIONS
}

\author{
Róbert HANÁK, Miroslav SIROTA, Marie JUANCHICH \\ Institute of Experimental Psychology, Slovak Academy of Sciences \\ Dúbravská cesta 9, 84104 Bratislava, Slovak Republic \\ E-mail: robohanak@gmail.com
}

\begin{abstract}
Previous research focusing on decision making has reported that most novices use an extensive set of cues in a compensatory way to make their decisions (i.e., compensatory strategies), whereas most experts use a limited set of relevant cues in a non-compensatory way (i.e., non-compensatory strategies). We tested the generalizability of these conclusions in a personnel selection context with students as novices and recruiters as experts. In a realistic setting, we investigated the effect of expertise on a subjective and an objective measure of decision making strategies. Results showed that, in contrast with previous research, both novices and experts mostly used compensatory strategies and that experts used them more often than novices. Further, consistently with previous research, experts allocated more importance than novices to cues predicting future job performance. We discussed theoretical and practical implications of our findings.
\end{abstract}

Key words: decision-making, personnel selection, compensatory, non-compensatory, expertise

Despite its obvious practical and theoretical importance, too little attention has been paid to descriptive models of decision-making in selection and recruitment. The aim of this paper is to shed light on decision-making strategies of novices and experts in personnel selection.

\section{Decision-Making Strategies}

When making decisions one can use a repertoire of strategies. In this article, the term decision strategy refers to a "sequence of mental and effector (actions on environment) operations used to transform an initial state of knowledge into a final goal state of knowledge" (Payne, Bettman, Johnson, 1993). These strategies refer to different procedures and potentially reach different outcomes (e.g., Dieckman, Rieskamp, 2007; GarciaRetamero, Rieskamp, 2008). The first and common stage of a decision-making strategy is to assess the importance of the different attributes or cues of the available options. For example, job experience and educational level of a candidate are cues in making a personnel selection decision-making. To assess the importance of each cue, one can rank the cues by importance or allocate a specific weight to each of them. Then, the decision maker does or does not make tradeoffs among the cues for the different options (Payne, Bettman, Johnson, 1993). It is at that last stage that major differences arise between decision-making strategies. Compensatory strategies involve trade-offs among all the available cues weighted according to their values. On the contrary, non-compensatory

DOI: $10.21909 /$ sp.2013.04.640 
strategies do not involve trade-offs among cues and their relative weights (Payne et al., 1993).

The Weighted Additive Strategy (WADD) is a typical compensatory decision strategy. In a nutshell, the WADD strategy is a systematic procedure focusing on one alternative at one time (e.g., one candidate after the other). After allocating a different importance and value to each cue, the subjective value of each cue is multiplied by its importance weight. Finally the results of each multiplication are summed (e.g., Garcia-Retamero, Rieskamp, 2008; Bergert , Nosofsky, 2007). As a result, the WADD is very robust and reliable but time consuming and information demanding, which is not suitable under time and cognitive constraints (e.g., Rieskamp, Otto, 2006; Bergert, Nosofsky, 2007; Broder, Gaissmaier, 2007). A strategy enabling the decision-maker to cope with time pressure and limited information access is the Take the Best strategy.

The Take the Best strategy (TTB) is a typical non-compensatory strategy. Using the TTB strategies includes different stages. After allocating a different importance and value to each cue, the decision maker compares the value of the most important cue among different options. If one option has a greater value than the others, this alternative will be chosen. If the values of the most important cue are the same among the different alternatives, the next cue is examined according to the same procedure until one of the cues has a greater value for one of the alternatives. If all cues have the same value the decision maker will choose randomly among them (Gigerenzer, Todd, 2001; Hogarth, Karelaia, 2006; Rieskamp, Otto, 2006).

To illustrate these strategies, consider the following hiring context in which the options for the decision maker are the different candidates and the cues their respective characteristics:

A recruiter is looking for a manager for a medium size factory. In the job profile, he selected three criteria according the relevance: education level, cognitive abilities and motivation. Two applicants pass a series of tests.

- Candidate A does not meet the education criteria but has very good performance on cognitive abilities and motivation test.

- Candidate B meets all the criteria but has lower performance on cognitive ability tests and motivation than candidate $\mathrm{A}$.

If weights of cues are not equal and values of cues are not dichotomous, a recruiter using a compensatory strategy would hire the applicant A, even if the education level does not satisfy one of the criteria. The decision is the result of a compensation of the cue "education level" by the value of the other cues relevant for the position. A recruiter using a non compensatory strategy would not hire applicant A since he does not meet the first of the criteria judged to be necessary for the position but applicant B who meets the first relevant criteria. Better performance of candidate $\mathrm{A}$ in cognitive abilities test and motivation cannot compensate for the lack of most relevant cue (stopping rule).

Because of its extensive processing of available information, the WADD strategy is accepted as a normative decision strategy (Frisch, Clemen, 1994). Indeed, in an ideal decision-making environment the systematic character of the WADD compensatory strategy is more likely to result in accurate decisions. However, this does not hold under time pressure or cognitive limitation (Payne et al., 1988). Using the WADD strategy in a 
very limited time or with low attention capacities could result in an interruption of the process before it leads to a result or to bad decisions based on computational errors (Payne, Bettman, 2002). On the other hand, the non systematic character of the TTB noncompensatory strategy does not guarantee that the best decision has been made but rather a satisfying decision, implying a limited cognitive effort and time cost (Gigerenzer, Goldstein, 1996). Overall, it cannot be concluded that the WADD or the TTB is the best strategy; their effectiveness depends on both the environment (e.g., information available) and the relationship between the decision maker's cognitive resources and the task's complexity, according to the notion of bounded rationality (Simon, 1982). As Gigerenzer and Todd (2001) suggested, individuals have a toolbox of decision-making strategies in which they choose the one deemed to be the most suitable in a specific situation $^{1}$. As a result, a great amount of research has focused on the conditions of the use of one or another strategy, testing the adaptive nature of decision-making strategies.

\section{The Effect of Expertise in Decision-Making Strategy Choice}

Different factors determine the use of different strategies such as time constraint, amount of information available, and the type and structure of the task at hand (e.g., Shanteau, 1992a; Bergert, Nosofsky, 2007). The degree of expertise of the decision maker is also deemed to determine the choice of

\footnotetext{
${ }^{1}$ Ballová Mikušková (2013) explains how people are able to switch from intuitive to deliberative mode according to a specific situation.
}

decision-making strategy. Experts and novices use different decision strategies to achieve the best outcome (Shanteau, 1992a; Garcia-Retamero, Dhami, 2009). Indeed, the difficulty in identifying the most important cue would prevent novices selecting the TTB strategy. Furthermore, novices are held to rely on explicit, controlled and slower processes, whereas, experts rely on implicit and fast processes and use less but more relevant pieces of information (Shanteau et al., 1991; Garcia-Retamero, Dhami, 2009). Experts may employ non-compensatory strategies, whereas novices may rely on more cognitively complex strategies. In a study focusing on burglars' decision-making strategies, Garcia-Retamero and Dhami (2009) found that expert burglars used the TTB strategy more than novices. When assessing house safety, expert burglars used the TTB decision strategy in $85 \%$ of the cases whereas novices (students) in only $2.5 \%$. Similarly, Shanteau (1992b) concluded that experts use TTB more often than lay individuals in audit tasks. Decision-making strategies are highly context dependent since the choice of strategy is determined by contextual factors and the relevance of the cues is a function of the goal of the decision-maker. The potential to generalise findings in one context to another is very poor (Shanteau, 1992a).

In contrast to these findings, Highhouse (2008) disputed the effect of expertise on decision-making strategies by emphasising the negative effect of expertise on personnel selection practice. In the personnel selection context, Highhouse found that three expert practitioners out of four believed that they could assess the suitability of a candidate more accurately with an informal discussion than with specific selection tests (i.e., used non-predictive cues). This could be because 
experts believe that their expertise enables them to rely more on their own intuition rather than to rely on formal procedures such as selection tests (see also Čavojová, 2013). In this study, we explore how novices and experts weigh cues and select strategies when making personnel selection decisions. Experts are assumed to use a smaller set of most relevant information (Weiss, Shanteau, 2003), but what are the relevant cues in a hiring decision?

\section{Weighting the Cues in a Personnel Selection Situation}

When making a decision in recruitment, the first step is assessing the importance of the different characteristics of the applicants (e.g., job experience, job related knowledge). During this process, the decision-maker allocates specific weights to the different cues that will be used according to the preferred decision strategy. Assessing the importance of the characteristics of a candidate amounts to assessing to what extent these characteristics predict performance at the organisational level. This is a real challenge in practice and therefore, an important issue for researchers. Choosing the right candidate represents a high stake for any organisation, as good selection decisions result in higher levels of annual profit for an organisation (Terpstra, Rozell, 1993).

A very wide variety of characteristics are considered to assess whether a candidate is suitable for a position. However, some of these characteristics are not relevant to selecting an individual, as they are not predictive of future performance. Schmidt and Hunter (1998) have made an overview of the predictive validity of applicants' characteristics showing that cues commonlyused in the past were in fact not predictive of job performance. For example, graphology, age and interests had no predictive validity on overall job performancebut we used them in our research for measuring the participants' awareness of the cues predictive validity. The belief of practitioners in the relative efficiency of selection procedures or tools partly explains their willingness to integrate such tests in their practice(Terpstra, Rozell, 1997). For example, the main reason why some American HR managers did not use cognitive ability tests in the nineties is that the tests were perceived as non-useful (Terpstra, Rozell, 1997). Although organisational psychology research brought clear evidence of the value of different cues, findings failed to be fully implemented in practice. Different papers describe how research and practice fail to meet and work in synergy for mutual benefit (e.g., Anderson et al., 2004; Nowicki, Rosse, 2002). One of the guidelines to bridge the gap between research and practice would be to focus more specifically on a descriptive model of behaviour rather than normative or prescriptivemodels (Anderson etal., 2004). Consistent with this recommendation, this research focuses at a descriptive level on how experts and novices allocate importance to a set of characteristics of job applicants traditionallyused in selection procedure.

\section{GOALAND HYPOTHESES}

In the current research, we investigated decision-making strategies as a function of expertise in hiring decisions. Our goal is twofold: 1) comparing the decision strategies used by experts and novices in a personnel selection situation; 2) comparing differences in weighing of cues between experts and novices in personnel selection. Following 
findings of previous studies, we expect that experts will mostly adopt the TTB strategy whereas novices will mostly adopt the WADD strategy. We are aware that experts in recruitment make mistakes and they are not reaching optimal level of performance, however, we expect that experts will allocate greater weight to cues predicting future performance (i.e., cognitive abilities) than novices and less weight to cues not predicting future performance (i.e., graphology).

\section{METHOD}

\section{Participants}

In this study 46 participants volunteered to participate without financial incentive. Two similarly sized groups were formed. The expert group consisted of people who regularly recruit candidates for job posts. To be classified as an expert all of the following criteria had to be met: at least two years of experience in the field; experience of hiring at least 50 people with responsibility for the whole selection process and final decision. The sample of recruiters consisted of 21 recruiters with an average of 6.1 years of experience $(\mathrm{SD}=4.1$ years), and an average of 172 positions recruited $(\mathrm{SD}=215.3$ positions). The average age of the recruiter sample was 32.3 years old $(\mathrm{SD}=10.6$ years) and most of them were women $(n=16)$. The novice group consisted of 25 undergraduate management students at the University of Economics in Bratislava, Slovakia. None had any experience with personnel selection as a recruiter nor had they received any relevant training, such as human resources management classes. All participants in the novice sample were aged 20 years old and most were male $(\mathrm{n}=14)$.

\section{Materials and Procedure}

The hiring task was designed to enable the authors to identify whether the decision was made using a WADD strategy or a TTB strategy based on a final choice of one out of the two candidates in each of four trials. We, therefore, refer to this procedure as being outcome-based. The hiring task procedure involved two stages, each composed of several steps. In the first stage, participants were first informed of their personnel selection objective: You would like to hire a sales person to sell luxury cars and you are looking for the best salesperson available. Then they were provided with a table exhibiting nine job-hiring cues. These were selected and categorised based on Hunter's and Schmidt's (1998) review of the literature on cues used in selection procedures and their predictive validity (i.e., to what extent they predict future performance in the position). Three cues were not predictive of future performance: graphology, hobbies and education $(\mathrm{r}<.11)$ and six cues were predictive of future performance: collaborator's assessment, job experience, references, cognitive tests, assessment centre and specific job knowledge $(r>.18)$. Participants were asked to rate the subjective importance of each cue in accordance with the specific job post. They received 100 points, which they allocated among the 9 characteristics. The number of nine characteristics was inspired by Garcia-Retamero and Dhami (2009) research who used 8 characteristics in a similar task.

The second stage of the procedure involved four decision choices between two candidates. For both candidates, 9 characteristics (i.e., cues) were presented simulta- 
neously. The value of each cue was in a binary mode either positive or negative. For example, a positive value of the cue Education, was described as follows, "The applicant is a university graduate with very good results, having studied international trade"; whereas a negative value for the same cue was described as follows "The applicant successfully finished High School with very good results, having studied trade as a specialty".

To ensure that the choice of one of the two candidates was the result of either the WADD or the TTB strategy, the composition of the choices in each trial was designed as a function of the individual ranking and weights of cues provided by the participant in the first stage. This procedure was the same as that used in Lee and Cummins (2004). All trials were presented on a computer screen (Microsoft Excel was used) and all data were collected in individual sessions or by email.

Finally, after completing the four decision trials, participants were asked to complete a short self-report questionnaire on decision-making strategies. Participants were informed that two different strategies could be used in personnel selection (WADD and TTB) and these were briefly described. Participants then reported which of the two strategies they used in the hiring decision task, and which they would use in hiring decision without limitation (e.g., time, cost). Furthermore, participants responded to three further items investigating how they think HR managers usually make hiring decisions, how managers without HR training make hiring decisions and finally, how students in management would make hiring decisions. Judgments were collected on a 5-point Likert scale ranging from 1: WADD to 5 : TTB $(1,2,3$ indicated WADD and 4, 5 indicated TTB).

\section{RESULTS}

\section{Decision-Making Strategies of Experts and Novices}

On average over the four trials, participants used the WADD strategy $(82.1 \%$, CI [ $75.9 \%$, $87.0 \%]$ ) more often than the TTB strategy $(17.9 \%$, CI $[13.0 \%, 24.1 \%])$. We expected experts to mostly use the TTB strategy but, on the contrary, results showed that experts used the WADD strategy $(\mathrm{M}=91.7 \%, \mathrm{SD}=$ $14.4 \%)$ more than the TTB ( $\mathrm{M}=8.3 \%, \mathrm{SD}=$ $14.4 \%)$. In agreement with our prediction, novices used the WADD strategy $(\mathrm{M}=$ $74.0 \%, \mathrm{SD}=31.9 \%)$ more than the $\mathrm{TTB}(\mathrm{M}=$ $26.0 \%, \mathrm{SD}=31.9 \%$ ). Most importantly, when we compared differences between novices and experts in strategy selection, contrary to our prediction, experts used the TTB strategy less than novices, $t(34,7)=-2.49, p=$ $.018, \mathrm{CI}[-32.1 \%,-3.2 \%], \mathrm{d}=0.70$.

The surprising role of expertise in selection of decision-making strategies may have occurred due to possible confounding variables such as gender (novices were mostly males and experts mostly females) or age (novices were younger than experts). We controlled the possible confounding variables statistically by using a linear regression modelling approach. According to this approach, evidence of confounding occurs when a slope of the main variable of interest decreases by entering confounding variables into a multiple linear regression. A simple linear regression of expertise on strategies yielded a significant slope of expertise, $(b=-0.71, \beta=-.33 ; t=-2.34, p=.024)$, which has even increased - not decreased 
$(b=-0.99, \beta=-.47)$ - by entering the additional two variables, gender and age, into a multiple regression analysis. Indeed, the adjusted association between expertise and strategy selection was marginally statistically significant, $\mathrm{t}=-1.81, \mathrm{p}=.077$, whereas gender and age failed to predict significantly strategy selection (respectively, $\beta=.21 ; \mathrm{t}=$ $1.35, \mathrm{p}=.184 ; \beta=-.08 ; \mathrm{t}=-0.34, \mathrm{p}=.739)$. Therefore, gender or age, cannot account for the found association between expertise and strategy use despite their unbal-

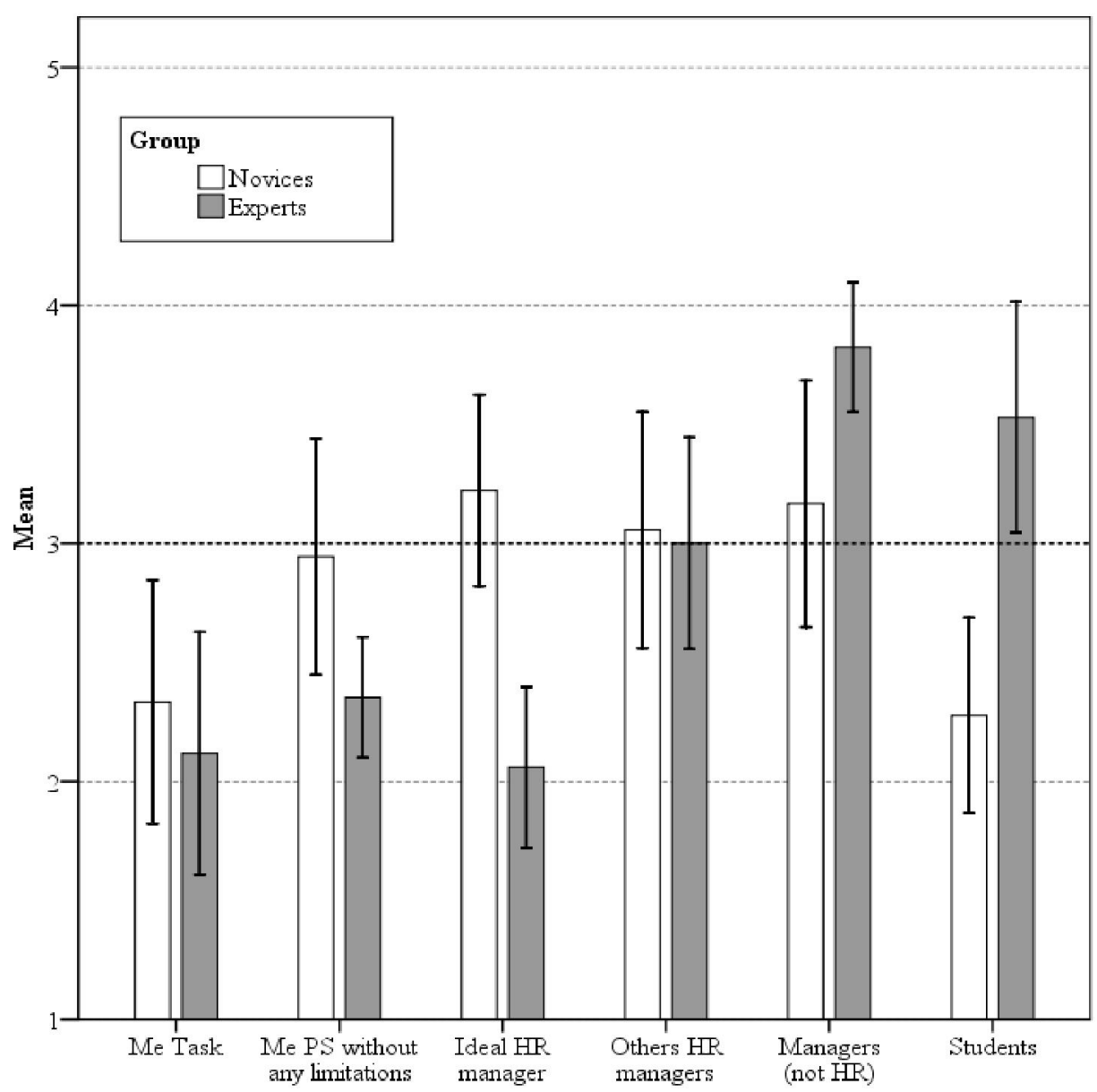

Note: Error bars represent $95 \%$ confidence intervals.

Judgments were given on a 5-point Likert scale ranging from 1: only WADD to 5: only TTB.

Figure 1. Differences in self-reported use of decision strategies between experts and novices 
anced distributions across the two expertise groups.

Results from the self-assessment of the usual strategy use are consistent with the results of the strategies traced in the hiring task. Overall, participants reported that in the hiring task they used the WADD strategy more $(M=2.13, S D=1.00)$. Furthermore, differences in self-report of strategies varied according to degree of expertise. Experts reported significantly different strategies (WADD) than novices (TTB) and the results in strategy traced in the hiring task were different as well.

As Figure 1 shows, experts reported that they used the TTB strategy less so than novices did (respectively, $\mathrm{M}=1.95, \mathrm{SD}=$ $0.97, \mathrm{M}=2.28, \mathrm{SD}=1.02) ; \mathrm{t}(39)=2.34, \mathrm{p}=$ $.024, \mathrm{CI}[0.08,1.05], \mathrm{d}=0.33$. Participants reported that without any constraints they would similarly use the WADD strategy $(\mathrm{M}=2.66, \mathrm{SD}=0.96)$. The correlation between decision-making strategies in hiring decisions and self reported strategies for hiring decisions were statistically significant and of medium size $(\mathrm{r}=.43, \mathrm{p}=.003)$. This means, that once the strategies were explained, participants were aware of the type of decision strategy they used.

Concerning what participants thought about the strategy used by others, we found that participants judged that an ideal HR manager and HR students would use the WADD strategy (respectively, $\mathrm{M}=2.66$, $\mathrm{SD}=0.06 ; \mathrm{M}=2.85, \mathrm{SD}=1.05)$. On the contrary, HR managers in general and managers without HR training were expected to use the TTB strategy (respectively, $\mathrm{M}=3.10, \mathrm{SD}$ $=0.94 ; \mathrm{M}=3.38, \mathrm{SD}=0.99$ ).

Overall, findings pointed to the prevailing use of the WADD strategy in hiring decisions by both experts and novices. However, this preference was greater for expert recruiters. These conclusions were supported by both strategies traced in actual decisionmaking and by self-report of strategy use in everyday practice.

\section{Importance Given to Cues Describing Applicants According to Expertise}

With regards to the diagnosticity of cues, we focused on the weight given to the different cues available for the participants to judge "whom to hire".

In order to compare differences in cue weight estimations among experts and novices, a mixed ANOVA was conducted with cue weight as the dependent variable, degree of expertise as between-subject and cue as within-subject factor. As the weights of every participant should sum to $100 \%$, the main effect of the group was not explored and focus was on the interaction of expertise degree with cue. Results showed a significant within-subjects effect of cue and group $x$ cue interaction, $F(5,10)=37.83, p<$ $.001, \eta^{2}=.46 ; \mathrm{F}(5,10)=4.71, \mathrm{p}<.001, \eta^{2}=.10$. This result shows that experts and novices did not allocate the same importance to the different cues.

More specifically, we expected experts to give more weight to relevant cues (i.e., specific job knowledge) than novices and novices to give more weight to less relevant cues (i.e., graphology). Thus, the group of 9 cues was split into two categories: predictive and non-predictive of future job performance according to Schmidt and Hunter's review (1998). As a result, collaborator's assessment, job experience, references, cognitive tests, assessment centre and specific job knowledge were categorised as predictive cues (see left panel 
of Figure 2); whereas graphology, hobbies and education were categorised as non-predictive (see right panel of Figure 2). On average, experts allocated more importance to predictive cues than novices (respectively, $\mathrm{M}=13.90, \mathrm{SD}=1.39$ vs., $\mathrm{M}=12.21$, $\mathrm{SD}=1.18), \mathrm{t}(44)=4.46, \mathrm{p}<.001$, CI $[1.85$,
4.91], $\mathrm{d}=1.31$. Furthermore, novices allocated more importance to non-predictive cues than experts (respectively, $\mathrm{M}=8.90$, $\mathrm{SD}=2.37 ; \mathrm{M}=5.52, \mathrm{SD}=2.78), \mathrm{t}(44)=4.46$, $\mathrm{p}<.001$, CI [2.46, 0.93], $\mathrm{d}=1.31$. Comparing significance and effect size, we could see that in predictive and non-predictive cues

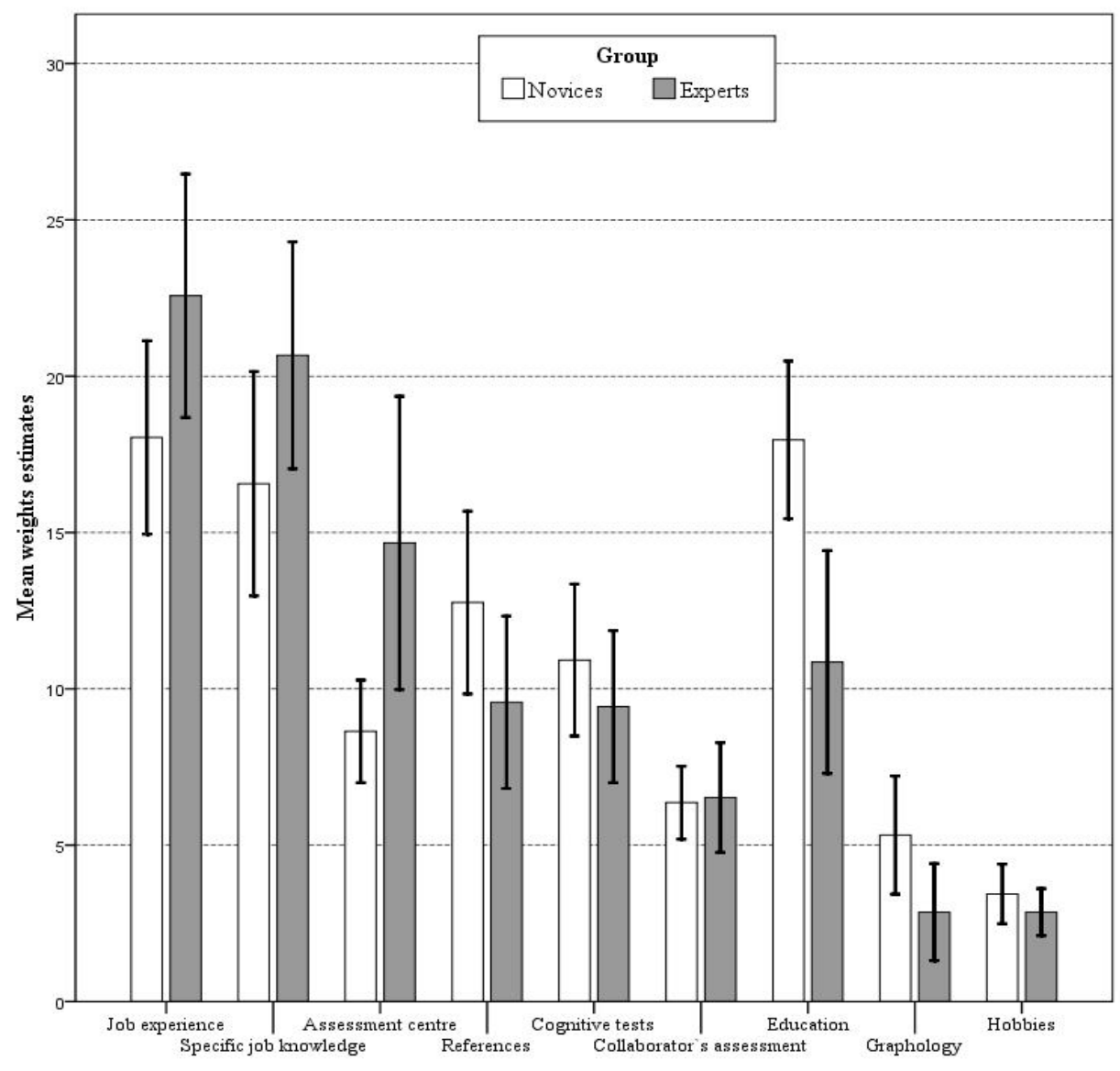

Note: Error bars represent $95 \%$ confidence intervals.

Not relevant cues: years of education, graphology, hobbies

Figure 2. Experts and novices mean weights allocated to the six job relevant cues and to the three not relevant cues right panel 
the difference between groups in cue weight are almost the same. To further analyse the weight allocated to each cue, we considered them individually. From the confidence intervals (Figure 2) it is apparent that experts' mean cue weights were statistically significantly higher than those of novices for the predictive cue 'assessment centres' $(d=0.79)$, and smaller for the non-predictive cue 'years of education' $(\mathrm{d}=-1.00)$ and 'graphology' $(\mathrm{d}=-0.59)$. Other differences were not statistically significant, however, medium effect sizes were identified. Experts allocated more importance to the predictive cues 'job experience' $(\mathrm{d}=0.56)$ and 'specific job knowledge' $(\mathrm{d}=$ 0.48 ) than novices. Conversely, the weight allocated to the predictive cue 'references' was smaller for experts than for novices $(d=-0.47)$.

\section{DISCUSSION}

The present study was designed to determine the extent to which decision strategies and decision quality of novices and experts differ in a hiring context. The findings show that experts used the compensatory Weighted ADDitive (WADD) strategy more often than the non compensatory Take The Best (TTB) strategy to determine whom to hire. Novices did not use the WADD strategy more than experts; to the contrary, they used the TTB strategy most often. These results of the strategy tracing procedure were consistent with the self-reported strategy use. In addition, experts allocated greater weight than novices to cues predicting future performance (i.e., cognitive abilities) and less weight to cues not predicting future performance (i.e., graphology).

\section{Both Novices and Experts Use Compensatory Strategies}

We found that both novices and experts use compensatory strategies. This finding showed, for the first time to our knowledge, the important role of expertise in choosing a decision strategy for personnel selection. Our results are inconsistent with previous findings showing that experts use TTB more than the WADD decision strategy (e.g., Shanteau, 1992a; Bergert, Nosofsky, 2007; Broder, Gaissmaier, 2007). For example, GarciaRetamero and Dhami (2009) showed that expert robbers used the TTB strategy more than WADD strategies when deciding which house they should burgle. Contrary to previous findings, experts did not use only relevant pieces of information compared with novices; they used all the information and made trade-offs among them even more often than novices. This result also appears to contrast with Highhouse's findings (2008) that expert HR managers rely on intuitive processes rather than analytical ones.

\section{Why Did Experts Mostly Use a Compensatory Strategy?}

Two main explanations why experts mostly used a compensatory strategy can be suggested to account for the discrepancy between previous findings and our results. The first explanation focuses on the task and the materials used in the present study and the second on the specificity of the personnel selection issue.

First of all, a tendency for preferring the WADD strategy by professional recruiters and also by novices could be explained by the design of the hiring task. Indeed, task 
characteristics have an important impact on decision-making strategy selection (Shanteau, 1992a). The procedure was designed to ensure that all cues were available at the same time to the decision-makers in the form of a table. Presenting all the cues at the same time and in a format facilitating comparison may have prompted participants to take them all into account. However, GarciaRetamero and Dhami (2009) used a similar task format and still found a predominance of TTB strategies for experts.

A second, and probably more relevant, explanation of the discrepancy with previous findings relates to the unique context of personnel selection and the (high) stakes of the hiring decision. Selecting individuals to fulfil expectations for a specific job is a costly, risky and time-consuming process (Hunter, Smith, 1998) and has to be professionally justified if asked by third party. All job candidates have the right to ask why they were unsuccessful or successful, as well as managers and even special commissions. Therefore, when so many resources are being expended, recruiters are expected to use the most sophisticated and complex methods. Using a decision strategy like the fast and frugal TTB strategy could appear as a lack of competence and professionalism; whereas using the WADD strategy (because it is exhaustive and complex) could appear as a symbol of competence and professionalism. Furthermore, from an ethical perspective, it can be considered that choosing a candidate from among many others, can only be fair if all the cues are examined - the selection has to be justified. One could argue that a decision context, where no cue completely outweighs the other, reduces the possibility of using the TTB strategy. We do not believe this was the case here. In addition, ac- cording to Gigerenzer and Goldstein (1996), when no cue outweighs the others, a decision-maker using the TTB strategy should choose an option randomly, which did not happen in our sample.

\section{Experts Identified More Relevant Cues than Novices}

Our results suggest that experts differed substantially from novices in setting cue weights to the characteristics of the applicants; mainly in weighing 'assessment centres', 'years of education', and 'graphology'. Experts allocated more importance to cues predicting future organisational performance (i.e., job experience) when compared with novices. Conversely, novices allocated more importance to cues not predicting future performance (i.e., hobbies). However, it is worth noting that although experts better identified the cues relevant to the hiring decision than novices, they failed to allocate zero weight to irrelevant cues. This finding is in line with the results of Highhouse (2008) showing that HR managers were using nonpredictive cues to make a hiring decision. However, contrary to his suggestion, such malpractice does not seem to be caused by expertise since in these results expertise appears to improve the identification of relevant cues.

\section{Concluding Comments}

The present research sheds light on the choice of decision-making strategy and its relation to expertise in offering a controversial finding. If substantiated by further research, these findings represent an important contribution to the domain of decisionmaking strategy and expertise. To rule out 
the effect of the mode of presentation as a determinant of the use of WADD, future studies should investigate the effect of various modes of presentation of job applicants on the hiring decision. More ecological formats could be studied, such as the traditional cover letter and Curriculum Vitae. Furthermore, these findings are specific to the personnel selection context. Since the choice of decision-making strategy is context dependent, further study is needed in other applied settings. Finally, the better performance of experts than novices in cue weighing indicates the need of training and experience to enhance practice. A potential implication of the present findings for practitioners is that it highlights the potential needs of mentoring new recruiters.

Received August, 29, 2012

\section{REFERENCES}

ANDERSON, N., LIEVENS, F., VANDAM, K., RYAN. M., 2004, October future perspectives on employee selection: Key directions for future research and practice. Applied Psychology, 53, 4, 487501 .

BALLOVÁ MIKUŠKOVÁ, E., 2013, Intuícia: Dobrý sluha, zlý pán? In: R. Hanák, E. Ballová Mikušková, V. Čavojová (Eds.), Rozhodovanie a usudzovanie IV. (pp. 33-47). Bratislava: Ústav experimentálnej psychológie SAV.

BERGERT, B., NOSOFSKY, R., 2007, A responsetime approach to comparing Generalized Rational and Take-the-Best models of decision making. Journal of Experimental Psychology: Learning, Memory and Cognition, 33, 107-129.

BRODER, A., GAISSMAIER, W., 2007, Sequential processing of cues in memory-based multiattribute decisions. Psychonomic Bulletin Review, 14, 895-900.

ČAVOJOVÁ, V., 2013, O racionalite intuície. In R. Hanák, E. Ballová Mikušková, V. Čavojová (Eds.), Rozhodovanie a usudzovanie IV. (pp. 1133). Bratislava: Ústav experimentálnej psychológie SAV.
DIECKMAN, A., RIESKAMP, J., 2007, The influence of information redundancy on probabilistic inferences. Memory Cognition, 35, 1801-1813.

FRISCH, D., CLEMEN, R.T., 1994, Beyond expected utility: Rethinking behavioral decision research. Psychological Bulletin, 116, 46-54.

GARCIA-RETAMERO, R., DHAMI, M., 2009, Take the best in expert-novice decision strategies for residential burglary. Psychonomic Bulletin Review, 16, 163-169.

GARCIA-RETAMERO, R., RIESKAMP, J., 2008, Adaptive mechanisms for treating missing information: A simulation study. The Psychological Record, 58, 547-568.

GIGERENZER, G., GOLDSTEIN, D., 1996, Reasoning the fast and frugal way: Models of bounded rationality. Psychological Review, 103, 650-669.

GIGERENZER, G., TODD, P., 2001, Simple heuristics that make us smart. New York: Oxford University Press.

HIGHHOUSE, S., 2008, Stubborn reliance on intuition and subjectivity in employee selection. Industrial and Organizational Psychology, 1, 333342.

HOGARTH, R., KARELAIA, N., 2006, "Take the best" and other simple strategies: Why and when they work "well" in binary clues. Theory and Decision, 61, 205-249.

LEE, M., CUMMINS, T., 2004, Evidence accumulation in decision making: Unifying the „take the best" and "rational“ models. Psychonomic Bulletin and Review, 11, 343-352.

NOWICKI, M.D., ROSSE, J.G., 2002, Managers' views of how to hire: Building bridges between science and practice. Journal of Business and Psychology, 17, 157-170.

PAYNE, J.W., BETTMAN, J.R., 2002, Preferential choice and adaptive strategy use. In: G. Gigerenzer, R. Selten (Ed.), Bounded rationality: The adaptive toolbox (pp. 123-145). Dahlem: MIT Press.

PAYNE, J.W., BETTMAN, J.R., JOHNSON, E.J., 1993, The adaptive decision maker. Cambridge: Cambridge University Press.

PAYNE, J.W., BETTMAN, J.R., JOHNSON, E.J., 1988, The adaptive strategy selection in decision making. Journal of Experimental Psychology: Learning, Memory and Cognition, 14, 534552.

RIESKAMP, J., OTTO, P., 2006, SSL: A theory how people learnt to select strategies. Journal of Experimental Psychology, 135, 207-236. doi: 10.1037/0096-3445.135.2.207 
SCHMIDT, F.L., HUNTER, J.E., 1998, The validity and utility of selection methods in personnel psychology: Practical and theoretical implications of 85 years of research findings. Psychological Bulletin, 124, 262-274.

SHANTEAU, J., 1992, Competence in experts: The role of task characteristics. Organizational Behaviour and Human Decision Processes, 53, 252-266.

SHANTEAU, J., 1992, How much information does an expert use? Is it relevant? Acta Psychologica, 81, 75-86.

SHANTEAU, J., GRIER, M., JOHNSON, J., BERNER, E., 1991,. Teaching decision making skills to student nurses. In: J. Baron, R.V. Brown
(Eds.), Teaching decision making to adolescents (pp. 185-206). Hillsdale, NJ: Lawrence Erlbaum Associates.

SIMON, H.A., 1982, Models of bounded rationality. Cambridge, MA: MIT Press.

TERPSTRA, D., ROZELL, E., 1993, The relationship of staffing practises to organizational level measures of performance. Personnel Psychology, 46, 27-48.

TERPSTRA, D., ROZELL, E., 1997, Sources of human resource information and the link to organizational profitability. Journal of Applied Behavioral Science, 33, 66-83.

WEISS, D., SHANTEAU, J., 2003, Empirical assessment of expertise. Human Factors, 45, 104-116.

\title{
PRI ROZHODOVANÍ O PRIJATÍ DO ZAMESTANIA POUŽÍVAJÚ EXPERTI KOMPENZATÓRNE STRATÉGIE ČASTEJŠIE AKO NOVÁČIKOVIA
}

\author{
R. H a nák, M. S i r o t a, M. J u a n c h i c h
}

Súhrn: Predchádzajúci výskum ukázal, že väčšina začiatočníkov využíva rozsiahly počet premenných kompenzatórnym spôsobom pri rozhodovaní (t.j. kompenzatórne stratégie), kým väčšina expertov využíva obmedzený počet relevantných premenných nekompenzatórnym spôsobom (t.j. nekompenzatórne stratégie). Testovali sme všeobecnú platnost' týchto záverov v kontexte personálnych výberov na vzorke študentov ako začiatočníkov a skúsených rekruiterov ako expertov. V realistickom prostredí sme skúmali účinok expertnosti na subjektívne a objektívne meranie rozhodovacích stratégií. Výsledky ukázali, že oproti predchádzajúcemu výskumu aj začiatočníci aj experti používali najmä kompenzatórne stratégie a experti ju používali častejšie než začiatočníci. V zhode s predchádzajúcim výskumom, experti viac než laici priradili pri rozhodovaní vyššiu váhu premenným, ktoré mali vyššiu prediktívnu validitu. Diskutovali sme teoretické a praktické implikácie našich zistení. 